\title{
AKSESIBILITAS PENDIDIKAN BAGI KAUM DISABILITAS PADA MADRASAH IBTIDAIYAH NEGERI (MIN) DI KOTA BANJARMASIN
}

\author{
Syarifah Salmah dan Tamjidnoor \\ UIN Antasari Banjarmasin \\ syarifahsalmah@uin-antasari.ac.id
}

Diterima 17 Juni 2019 | Direview 24 Juni 2019 | Diterbitkan 25 Juni 2019

\begin{abstract}
The government guarantees the equal and same rights to access education. But the problem is, is it true that education can be accessed by all levels of society without exception, including those with disabilities? We must look at the issue of education for individuals with special needs through its implementation or in other words whether schools really have accepted disabled people to enjoy regular education like other children. This study aims to find out how schools within the Ministry of Religion, especially at the level of State Islamic Elementary School (MIN), as an institution that is authorized to implement the government policies that provide easy and equitable access to education. This research is a survey research conducted on 5 state Islamic elementary schools with research time starting from July 2018 to December 2018. The target population is all MIN, and all of them will be observed in depth. From the results of the study we can conclude that all of the State Islamic Elementary School (MIN) in Banjarmasin are not responsive to disability. This is indicated by the absence of supporting facilities for this matter and there are no disability students who attend all these MIN. Then the socialization of the related legal basis is indeed unknown to the school as an executor who directly serves the community.
\end{abstract}

Keywords: Disability, accessibility, public facilities.

\begin{abstract}
Abstrak
Pemerintah menjamin hak yang sama untuk mengakses pendidikan bagi selurub lapisan masyarakat tanpa terkecuali. Tetapi yang menjadi permasalahan adalah, apakah benar pendidikan dapat diakses oleh seluruh lapisan masyarakat tanpa terkecuali termasuk bagi kaum disabilitas. Isu pendidikan bagi individu berkebutuhan khusus ini harus kita libat melalui dilibat dari implementasinya atau dengan kata lain apakah sekolah benarbenar telah menerima kaum disabilitas untuk menikmati pendidikan regular
\end{abstract}




\begin{abstract}
seperti anak-anak lainnya. Penelitian ini bertujuan untuk mengetahui bagaimana sekolah yang berada di lingkungan Kementrian Agama khususnya pada tingkat Madrasah Ibtidaiyah Negeri (MIN) sebagai pelaksana kebijakan pemerintah, melakukan upaya akses pendidikan yang adil dan merata. Penelitian ini menrupakan penelitian survey serta dilaksanakan pada selurub MIN di Kota Banjarmasin yang berjumlah 5 MIN dengan waktu penelitian mulai dari tanggal Juli 2018 sampai dengan Desember 2018. Populasi target adalah seluruh MIN yang berjumlah 5 dan semuanya akan di observasi secara mendalam. Dari hasil penelitian dapat kami simpulkean babwa selurub Madrasah Ibtidaiyah Negeri (MIN) di Kota Banjarmasin dapat kami katakan tidak layak disabilitas. Hal ini ditandai dengan tidak adanya fasilitas pendukung hal tersebut dan tidak ada pula siswa disabilitas yang bersekolah di semua MIN tersebut. Kemudian sosialisasi dasar hukum terkait memang tidak diketahui oleh pihak sekolah sebagai pelaksana yang langsung melayani masyarakat.
\end{abstract}

Kata kunci: Disabilitas, Aksesibiltas, Fasilitas Umum.

\title{
Pendahuluan
}

Pendidikan merupakan hak setiap warga Negara di Indonesia tanpa terkecuali. Tidak memandang agama, suku, ras dan hal yang berbeda diantara masyarakat Indonesia. Pendidikan pun menjadi hak bagi golongan masyarakat yang selama ini terpinggirkan (marginal) seperti golongan masyarakat disabilitas. Pada tataran dunia kita tentu juga memperhatikan adanya konvensi yang mengatur hak-hak penyandang disabilitas melalui resolusi PBB pada tanggal 13 Desember 2006. Indonesia juga telah meratifikasi konvensi ini pada tanggal 30 Maret 2007, untuk memastikan adanya hak yang sama bagi setiap warga Negara dan kaum disabilitas tanpa terkecuali.

Sebagai bukti kesungguhan pemerintah Indonesia dalam hal ini, maka dikeluarkanlah payung hukum untuk melindungi kaum disabel dengan Undangundang (UU) Nomor 8 Tahun 2016 tentang Penyandang Disabilitas. Salah satu bidang yang termuat dalam UU tersebut adalah hak pendidikan untuk penyandang disabilitas. ${ }^{1}$

Berkaitan dengan hal tersebut tentu setiap warga Negara khususnya para penyandang disabilitas mempunyai hak yang sama sebagai warga Negara Republik Indonesia dalam segala bidang, salah satunya adalah pendidikan. Pendidikan menjadi sangat penting dewasa ini, hal ini dikarenakan kesempatan

\footnotetext{
${ }^{1}$ Rahmad, "Pendidikan Setara Bagi Disabilitas,” Banjarmasin Post (Banjarmasin, 2017).
} 
manusia untuk berkembang salah satunya dapat diperoleh melalui proses yang dilalui dalam bidang pendidikan. Proses pengembangan diri dapat dilalui melalui bidang pendidikan. Pendidikan tentu tidak terlepas dari tri sentra pendidikan menurut Ki Hajar dewantara. Tri sentra tersebut adalah sentra pertama adalah keluarga, sentra kedua adalah lingkungan keluarga dan terakhir atau sentra ketiga adalah lingkungan masyarakat, yang akan membentuk kepribadian individu.

Pendidikan untuk individu berkebutuhan khusus lebih dari sekedar pengaturan teknis layanan pendidikan saja, melainkan sebuah praktik yang lahir dari kesadaran gerakan hak asasi manusia sehingga isunya terus berkembang searah dengan kompleksitas dinamika kemanusiaan itu sendiri. Individu berkebutuhan khusus termasuk populasi minoritas yang rentan terhadap diskriminasi dalam setiap aspek kehidupan. ${ }^{2}$ Pendidikan merupakan salah satu hak dasar dimana negara mempunyai kewajiban untuk mengusahakan dan menyelenggarakan satu sistem pendidikan nasional, yang meningkatkan keimanan dan ketakwaan serta akhlak mulia dalam rangka mencerdaskan kehidupan bangsa yang diatur dengan undang-undang seperti tertulis dalam pasal 31 ayat 3. Pada pasal 28 C Undang Undang Dasar 1945 pun dikatakan bahwa setiap orang berhak mengembangkan diri melalui pemenuhan kebutuhan dasarnya, berhak mendapat pendidikan dan memperoleh manfaat dari ilmu pengetahuan dan teknologi, seni dan budaya, demi meningkatkan kualitas hidupnya dan demi kesejahteraan umat manusia.

Hak dalam mengenyam pendidikan ini juga berlaku kepada orang berkebutuhan khusus atau kaum disabilitas atau yang biasa disebut difabel (different ability). Hak tersebut tertuang dalam konstitusi dasar kita yang menyebutkan bahwa setiap warga negara berhak mendapatkan pendidikan pada pasal $31^{3}$, pada dasar hukum lainnya disebutkan Pemerintah dan Pemerintah Daerah wajib memberikan layanan dan kemudahan, serta menjamin terselenggaranya pendidikan yang bermutu bagi setiap warga negara tanpa diskriminasi. ${ }^{4} \mathrm{Hal}$ tersebut diatas merupakan landasan hukum atas pemberian akses seluas luasnya kepada warga negara serta persamaan hak bagi setiap

\footnotetext{
2 Aini Mahabbati, "Kebijakan, Implementasi Dan Isu Strategis Pendidikan Bagi Individu Berkebutuhan Khusus," Jurnal Pendidikan Islam 3, no. 1 (2014): 31, http://jurnaljpi.com/index.php/JPI/article/view/38.

${ }^{3}$ Sekretariat Negara, Undang-Undang Dasar 1945, 2002, http://jdih.pom.go.id/uud1945.pdf.

${ }^{4}$ Kementrian Pendidikan Nasional, Undang-Undang No 20 Tabun 2003 Tentang Sistem Pendidikan Nasional, 2003, https://kemenag.go.id/file/dokumen/UU2003.pdf.
} 
warga negara untuk mendapat hak dalam pendidikan. Bahkan persamaan ini telah ada sebelum reformasi, yang menyebutkan bahwa setiap kaum disabilitas berhak memperoleh pendidikan pada semua satuan, jalur, jenis, dan jenjang pendidikan. ${ }^{5}$

Dengan kata lain, dalam sektor pendidikan formal seharusnya tidak ada lagi sekat sosial yang membedakan para difabel dengan masyarakat umum, sehingga jelas disini kewajiban umum negara dalam pemenuhan hak pendidikan adalah memfasilitasi (to facilitate), memajukan (to promote), menyediakan (to provide) bagi seluruh masyarakat Indonesia tanpa terkecuali.

Dalam dunia pendidikan juga muncul terminologi pendidikan inklusif yang mesti disediakan pada anak-anak yang memiliki kondisi tertentu. Namun pelayanan pendidikan sulit untuk disediakan. Apakah karena anak-anak masuk disebabkan berbagai kendala fisik, geografis, ekonomi dan social. ${ }^{6}$ Pengertian pendidikan inklusif menurut peraturan Menteri Pendidikan nasional nomor 70 tahun 2009 adalah sistem penyelenggaraan pendidikan yang memberikan kesempatan kepada semua peserta didik yang memiliki kelainan dan memiliki potensi kecerdasan dan/atau bakat istimewa untuk mengikuti pendidikan atau pembelajaran dalam satu lingkungan pendidikan secara bersama-sama dengan peserta didik pada umumnya. Kemudian masalah siapa yang menjadi peserta pendidikan inklusif, diperjelas melalui Permendiknas nomor 70 tahun 2009 yang menyatakan bahwa pendidikan inklusif bertujuan: memberikan kesempatan yang seluas-luasnya kepada semua peserta didik yang memiliki kelainan fisik, emosional, mental, dan sosial atau memiliki potensi kecerdasan dan/atau bakat istimewa untuk memperoleh pendidikan yang bermutu sesuai dengan kebutuhan dan kemampuannya. ${ }^{7}$ Dari pengertian ini dapat kita telaah bahwa kesempatan akan selalu terbuka bagi setiap orang yang memiliki kekurangan maupun kelebihan baik dari segi fisik, emosional, mental dan sosial

\footnotetext{
5 Sekertaris Negara RI, Undang-Undang No. 4 Tabun 1997 Tentang Penyandang Cacat, 1997, http://www.kpai.go.id/files/uu/UU-NOMOR-4-TAHUN-1997-TENTANGPENYANDANG-CACAT.pdf.

${ }^{6}$ Yusraini, "Kebijakan Pemerintah Terhadap Pendidikan Inklusif," Media Akademika Vol. 28 No (2013).

7 Kementrian Pendidikan Nasional, Peraturan Mentri Pendidikan Nasional Nomor 70 Tabun 2009 Tentang Pendidikan Inklusif Bagi Peserta Didik Yang Memiliki Kelainan Dan Memiliki Potensi Kecerdasan Dan/Atau Bakat Istimewa (Indonesia, 2009), http://kelembagaan.ristekdikti.go.id/wpcontent/uploads/2016/11/Permen-No.-70-2009-tentang-pendidiian-inklusif-memilikikelainan-kecerdasan.pdf.
} 
untuk dapat bersekolah secara formal serta berinteraksi dengan teman sebaya dan lingkungan dia berada.

Sekolah sebagai lembaga yang tepat untuk menghilangkan diskriminasi, tentu dalam praktiknya juga harus menghilangkan diskriminasi, melalui pemenuhan akses pendidikan bagi setiap warga Negara. Sekolah tentu sebagai lembaga resmi dapat mewujudkan hal tersebut utamanya adalah sekolah negeri sebagai instansi pelaksana kebijakan pemerintah.

Sekolah yang terbuka dan memiliki fasilitas yang mendukung terwujudnya akses bagi kaum disabilitas tentu memerlukan sebuah proses yang harus kita lalui bersama. Sinergi antara pemerintah sebagai pencetus kebijakan, pihak sekolah sebagai implementasi perwujudan kebijakan pemerintah, serta masyarakat sebagai penerima serta pengguna manfaat menjadi sebuah keharusan agar akses yang sama dalam bidang pendidikan menjadi sebuah hal yang memang dapat dilaksanakan secara umum.

Pola pendidikan inklusif merupakan suatu usaha untuk mengurangi bahkan menghilangkan hambatan yang dapat menghalangi setiap siswa dalam mengakses proses pendidikan, dengan kata lain pendidikan inklusif merupakan suatu alternatif untuk melayani pendidikan anak berkebutuhan khusus yang dididik bersama-sama anak lainnya (normal) untuk mengoptimalkan potensi yang dimilikinya. Salah satu kelompok yang coba diakomodir dalam pendidikan inklusif ini tentu adalah kaum disabilitas tapi ini bukanlah kelompok yang homogen. Sekolah dan layanan pendidikan tentu harus berusaha untuk memenuhi keberagaman kebutuhan siswa.

Berdasarkan uraian diatas dapat kita telaah bahwa dasar hukum tentang akses bagi kaum disabilitas dalam bidang pendidikan dan bidang lainnya sudah lengkap dimulai dari Undang undang dasar 1945 sampai peraturan daerah tentang hak-hak penyandang disabilitas, tetapi yang menjadi pertanyaan adalah apakah ini sudah benar diimplementasikan dalam praktiknya terutama di satuan pendidikan di bawah Kementrian Agama. Hal ini yang menjadi fokus utama penelitian ini serta mendapatkan masukan dari satuan pendidikan agar pendidikan inklusif dapat benar-benar dilaksanakan dan menjadi sebuah solusi bersama bagi masyarakat.

Penelitian ini akan memberi gambaran serta mengungkap fakta, keadaan, fenomena, variabel dan keadaan yang terjadi saat penelitian berjalan dan menyuguhkan apa adanya. Tujuan dari penelitian ini adalah untuk membuat deskripsi, gambaran, atau lukisan secara sistematis, faktual dan akurat mengenai fakta-fakta yang diselidiki. 
Penelitian ini menggunakan metode penelitian survey. Hal ini dikarenakan penelitian ini untuk mencari gambaran tentang akses pendidikan bagi kaum disabilitas, hal ini senada dengan pendapat yang mengklasifikasikan penelitian survey mempunyai dua tujuan, pertama bertujuan untuk memberikan gambaran/penjelasan tentang sesuatu dan kedua bertujuan untuk melakukan analisis. ${ }^{8}$

Ada dua macam jenis penelitian survey, yaitu : pertama, survey untuk memperoleh data dasar guna memperoleh gambaran umum yang bermanfaat untuk membuat perencanaan dan kebijakan public (misalnya sensus). Kedua, survey yang digunakan untuk mengungkapkan pendapat, sikap, dan harapan public (misalnya: prediksi suara pemilihan presiden). Yang pertama mengungkap fakta, yang kedua mengungkap efek suka tak suka. ${ }^{9}$

Penelitian ini diharapkan memberi gambaran serta memberikan solusi terhadap akses pendidikan tanpa diskriminasi di seluruh jenjang pendidikan pada bidang pendidikan Kementrian Agama.

\section{Signifikansi Pendidikan dalam Ajaran Islam}

Pentingnya ilmu (pendidikan) dapat kita telaah bersama pada surat $\mathrm{Al}$ Mujadilah ayat 11 sebagai berikut:

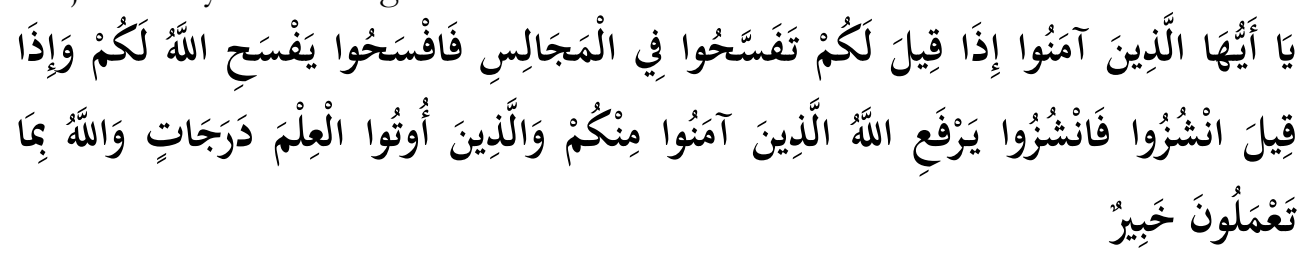

Hai orang-orang beriman apabila dikatakan kepadamu: "Berlapang-lapanglah dalam majlis", maka lapangkanlah niscaya Allab akan memberi kelapangan untukmu. Dan apabila dikatakan: "Berdirilah kamu", maka berdirilah, niscaya Allah akan meninggikan orang-orang yang beriman di antaramu dan orang-orang yang diberi ilmu pengetabuan beberapa derajat. Dan Allah Maha Mengetahui apa yang kamu kerjakan. (Qs. al Mujadilah: 11)

Ayat ini menjadi sebuah tolak ukur bahwa Islam begitu menghargai orang berilmu. Ilmu didapatkan tentu melalui berbagai Lembaga Pendidikan baik formal, non-formal maupun informal. Tetapi penelitian ini hanya mengkaji

\footnotetext{
${ }^{8}$ Irawan Soehartono, Metode Penelitian Sosial (Bandung: PT. Remaja Rosdakarya, 2002).

${ }^{9}$ Muhadjir, Metodologi Penelitian Kualitatif Edisi IV (Yogyakarta: Rake Sarasin, 2002).
} 
pada Lembaga Pendidikan formal dibawah Kementrian Agama saja. Pendidikan sebagai hak dasar setiap warga negara tentu menjadi sebuah hak dasar yang harus dipenuhi oleh negara, dan setiap warga negara berhak atas Pendidikan dengan asas keadilan dan setara.

Pada ayat lainnya atau tepatnya pada ayat Az Zumar :

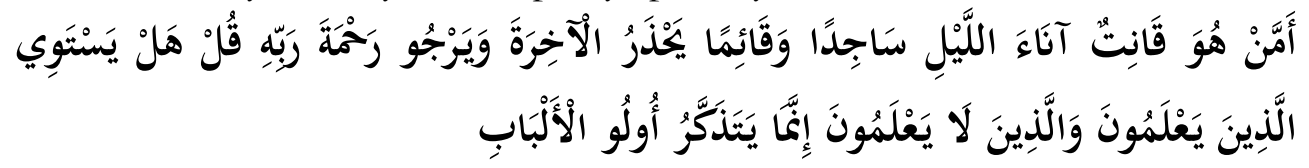

(Apakah kamu hai orang musyrik yang lebih beruntung) ataukah orang yang beribadat di waktu-waktu malam dengan sujud dan berdiri, sedang ia takut kepada (azab) akbirat dan mengharapkan rahmat Tubannya? Katakanlah: "Adakah sama orang-orang yang mengetabui dengan orang-orang yang tidak mengetahui?" Sesunggubnya orang yang berakallah yang dapat menerima pelajaran. (Qs. Az Zumar: 9)

Penegasan bahwa orang berilmu memiliki kedudukan yang baik. Hal ini menjadi sebuah penegasan kedudukan orang yang berilmu. Dasar hukum tentang akses pendidikan yang adil dan merata sudah ada di Republik ini. Dewasa ini ada sebuah tuntutan bagi peserta didik berkebutuhan khusus untuk memperoleh pelayanan dalam berbagai bidang, salah satunya adalah pendidikan. Apabila kita telaah bersama, saat ini dasar hukum tentang akses bagi kaum disabilitas dalam bidang pendidikan dan bidang lainnya sudah lengkap dimulai dari Undang undang dasar 1945 sampai peraturan daerah tentang hak-hak penyandang disabilitas, tetapi yang menjadi pertanyaan adalah apakah ini sudah benar diimplementasikan dalam praktiknya terutama di satuan pendidikan di bawah Kementrian Agama. Hal ini yang menjadi fokus utama penelitian ini serta untuk mendapatkan masukan dari satuan pendidikan agar pendidikan setara bagi seluruh masyarakat Indonesia yang memenuhi persyaratan, tidak terkecuali kaum disabilitas. Hal ini dimaksudkan agar pendidikan inklusif dapat benar-benar dilaksanakan dan menjadi sebuah solusi bersama bagi masyarakat utamanya di lingkungan pendidikan dasar negeri pada ruang lingkup Kementrian Agama Banjarmasin. 


\section{Gambaran Lokasi Penelitian}

1. MIN 1 Kota Banjarmasin

Berbicara mengenai akses menuju MIN 1 dapat dikatakan cukup baik namun belum bisa dikatakan ideal. Mengapa dikatakan belum ideal, dikarenakan fasilitas menuju Madrasah sudah dapat dilalui dengan baik. Kondisi bangunan sebagian besar telah permanen, akan tetapi memang akses menuju madrasah harus lebih diperbaiki lagi.

Kondisi lapangan upacara MIN 1 Kota Banjarmasin dapat dilihat melalui dokumentasi diatas. Sepintas terlihat cukup baik untuk dilalui pengguna kursi roda, namun ada beberapa bagian yang tidak rata atau cukup menyulitkan apabila dilalui kursi roda, kerusakan tersebut bisa dikarenakan faktor yang tidak dapat dihindari seperti akar pohon yang semakin membesar dan menjalar sehingga merusak lantai semen, ataupun karena faktor memang lantai semen tersebut yang rusak. Pada bagian selasar Madrasah akses juga dapat dikatakan baik apabila sudah berada di selasar, tetapi untuk menuju selasar kembali dapat dikatakan kurang ramah, karena perbedaan tinggi antara permukaan lapangan atau halaman dengan bagian selasar yang dihubungkan dengan tangga tanpa ada bidang miring penghubung. Terkait masalah kerusakan lantai halaman karena faktor alam maupun faktor lainnya penulis meyakini hal tersebut akan mampu diperbaiki oleh pihak madrasah.

Berbicara mengenai fasilitas penunjang sebuah bangunan seperti kamar kecil atau toilet, tentu juga harus fasilitas yang menunjang akses tersebut. Toilet pada MIN 1, akses menuju tempat tersebut boleh dikatakan mudah, namun untuk mempergunakan fasilitas tersebut masih belum standar karena luas toilet yang masih sulit untuk dipergunakan oleh siswa yang (kalau ada) berkursi roda. Hal tersebut semakin diperburuk dengan keadaan tinggi lantai antara bagian dalam toilet dan luar toilet yang berbeda tingginya, juga tidak disertai dengan bidang miring untuk memudahkan pengguna kursi roda. Bidang miring tentu merupakan sebuah upaya agar memudahkan akses tersebut.

Berdasarkan wawancara dengan pihak sekolah dalam hal ini Kepala Madrasah Negeri 1 Abdul Kadir, S.Pd.I., bahwa, tidak ada peserta didik yang merupakan peserta didik berkebutuhan khusus. Ketika hal ini ditanyakan lebih lanjut mengenai sosialisasi tentang peraturan yang terkait dengan akses kesetaraan disabilitas, pihak sekolah menjawab tidak ada sama sekali sosialisasi tersebut. Hal ini tentu akan menjadi masukan bagi 
pemerintah daerah untuk menyikapi temuan ini. Karena secara jelas dinyatakan bahwa pemerintah daerah pun dikatakan tidak ada melakukan sosialisasi dengan pihak MIN 1 Kota Banjarmasin mengenai Perda terkait. ${ }^{10}$

Tidak adanya sosialisasi terkait mengakibatkan ketidak tahuan dari pihak sekolah, dalam hal ini MIN 1 Kota Banjarmasin. Hal tersebut berdampak ketika ada pendaftar atau peserta didik yang berkebutuhan khusus akhirnya diarahkan untuk mendaftar di SLB yang memang sepengetahuan pihak sekolah merupakan sekolah yang dipersiapkan untuk peserta didik berkebutuhan khusus tersebut. Hal tersebut mengakibatkan pada tahap lanjutnya adalah para peserta didik berkebutuhan khusus tidak memiliki kesempatan untuk bergaul dengan peserta didik yang tidak berkebutuhan khusus. Hal ini membuat proses integrasi peserta didik di masyarakat umum (umur sebaya) menjadi sedikit terhambat.

Berbicara mengenai ketidak tahuan pihak sekolah dalam hal terkait, juga membuat pihak madrasah menjadi tidak ada persiapan dan tidak ada fasilitas yang dapat menunjang pemberlakuan sekolah yang bebas dan boleh menjadi salah satu pilihan pendaftar peserta didik berkebutuhan khusus. ketidaktahuan pihak Madrasah tentu menjadi sebuah pertanyaan besar bagaimana produk hukum yang dapat dikatakan baik tetapi pada pihak pelaksana atau ujung tombang pelayanan publik justru tidak mengetahuinya. Hal ini tentu menjadi sebuah anomali terkait pelayanan publik dan dasar hukum yang tidak diketahui oleh pelaksana atau penyelenggara kebijakan tersebut. Tetapi ini tentu akan menjadi sebuah masukan berharga bagi pemangku kebijakan kedepannya.

\section{MIN 2 Kota Banjarmasin.}

Penggunaan material pada selasar kelas di MIN 2 Kota Banjarmasin dapat dikatakan baik dan ideal. Hal tersebut didasarkan kepada lantai yang menggunakan porselin, penggunaan porselin bukan satu-satunya material yang dianggap ramah. Penggunaan material lantai semen juga dapat dikatakan baik dan ideal, karena kecenderungan material tersebut akan membentuk permukaan yang rata dan mudah diakses, sehingga memudahkan akses terhadapnya.

Keterbatasan tersebut terlihat melalui halaman yang memiliki permukaan tidak terlalu rata. Permukaan halaman yang tidak rata tersebut

${ }^{10}$ Wawancara dengan Abdul Kadir, S.Pd.I hari Rabu, 10 Oktober 2018 diruang Kepala Sekolah MIN 1 Banjarmasin 
memerlukan tenaga ekstra bagi peserta didik (kalau ada) yang menggunakan kursi roda. Hal tersebut semakin diperberat dengan bentuk penghubung halaman dengan selasar yang susunannya hanya berbentuk tangga tanpa ada bidang miring untuk aksesnya.

Penggunaan bata press sebagai lantai pada halaman MIN 2 dapat dilihat dari dua sudut yang berbeda, dari segi estetika memang hal tersebut baik terlihat. Tetapi terkadang penggunaan material tersebut dapat menimbulkan permukaan lantai menjadi tidak rata dan akan sedikit menyulitkan bagi pengguna kursi roda. Mengapa kami menilai penggunaan material tersebut, karena dalam Permen PU tersebut dijelaskan tentang adanya penerapan wajib perihal fasilitas umum lingkungan (ruang terbuka dan penghijauan) mengamanatkan ruang terbuka pasif pada setiap ruang terbuka yang diperuntukan untuk umum sebagai tempat interaksi sosial. Harus memenuhi teknis aksesibilitas yang ditetapkan dalam pedoman tersebut. Minimal menyediakan jalur pemandu masuk dan keluar serta tersedia ram untuk keluar masuk pengguna kursi roda.

Toilet atau kamar kecil yang terdapat di MIN 2 Kota Banjarmasin seperti terlihat pada gambar diatas ada beberapa hal yang perlu kita cermati bersama pada sisi kiri toilet tersebut tidak dapat dikatakan ramah bagi disabilitas karena lebar pintu yang tidak memudahkan pengguna kursi roda.

Wawancara dengan Kepala Madrasah Drs. Kamal Naser, S.Pd.I, disebutkan bahwa sosialisasi terkait Perda yang dikeluarkan Pemprov masih belum diketahui oleh pihak Madrasah. Hal ini menunjukkan ada informasi yang tidak didapatkan dengan utuh para penyelenggara pendidikan dalam hal ini MIN Kota Banjarmasin, kembali pihak penyelenggara tidak mengetahui hal tersebut. Tetapi dalam wawancara dengan beliau disebutkan bahwa pihak Madrasah pernah menerima siswa penyadang disabilitas karena masih layak untuk diterima untuk bersekolah di MIN 2 Kota Banjarmasin. Kemudian setelah dua tahun mengenyam pendidikan di MIN 2 selanjutnya pihak sekolah merekomendasikan untuk bersekolah di SLB. ${ }^{11}$

Hal tersebut dikarenakan untuk menerima siswa tersebut, pihak MIN 2 harus memiliki dua orang guru, satu untuk siswa pada umumnya dan satu untuk siswa khusus, hal ini juga memberatkan anggaran di MIN 2 karena harus menambah tenaga pendidik. Selanjutnya siswa disabilitas tersebut dalam praktiknya juga memang harus benar-benar dibimbing

${ }^{11}$ Wawancara dengan Drs. Kamal Naser pada tanggal 15 Oktober 2018 di MIN 2 Banjarmasin 
sehingga terkadang kurikulum yang telah ada harus diturunkan standarnya atau materi akan disesuaikan oleh guru kepada kelas yang ada siswa tersebut.

Temuan siswa disabilitas yang pernah bersekolah di MIN 2 Kota Banjarmasin memang harus diapresiasi, tetapi memang menyelenggarakan pendidikan setara ini harus benar-benar dipersiapkan sehingga program perlindungan ini haruslah menjadi sebuah kegiatan yang memang berfungsi sebagaimana yang diamanatkan dalam aturan hukum tersebut.

MIN 2 pun pernah menerima guru honor terkait bidang keilmuan Pendidikan Luar Sekolah (PLS) namun memang tidak dikhususkan mengajar untuk siswa disabilitas, atau dengan kata lain tidak dipekerjakan untuk khusus masalah akses pendidikan bagi disabilitas.

3. MIN 3 Kota Banjarmasin

Berdasarkan hasil observasi, sarana dan prasarana pendidikan yang ada di MIN 3 Kota Banjarmasin sudah lumayan bagus dan memadai untuk menunjang terlaksananya proses belajar mengajar, tetapi hal tersebut hanya bagi peserta didik kebanyakan, bukan bagi peserta didik seperti kaum disabilitas. Akses menuju lantai dua maupun masuk kelas pada lantai satu memang merupakan bangunan lama, tetapi tentu perlu sebuah inisiatif dan kemudahan akses untuk menuju tempat belajar atau ruang kelas bagi difabel gerak. Penggunaan tangga yang tidak menyediakan akses tentu menjadi pekerjaan dan perhatian bersama. Bentuk tangga yang terdapat di MIN 3 Kota Banjarmasin yang memiliki material kayu masih jauh dari kata ideal bagi kaum difabel. Lantai kelas dan selasar juga berbeda tingginya, kembali tidak ada sebuah penghubung seperti bidang miring yang menghubungkan antara selasar dengan ruang kelas tersebut.

Pada bagian lain fasilitas sekolah seperti toilet juga Nampak belum sesuai dengan standar yang ditetapkan, fasilitas yang ada pada MIN 3 tersebut masih ditujukan untuk peserta didik yang tidak memiliki kebutuhan khusus, atau masih dikatakan belum memadai.

Akses menuju kelas pun tentu harus diperhatikan. MIN 3 dalam praktiknya dapat dikatakan masih belum ramah, belum ramah tersebut dikarenakan untuk memasuki kelas atau ruang pembelajaran siswa yang menggunakan kursi roda akan kesulitan. Seperti MIN lainnya yang tinggi ruang belajar berbeda dan tidak ada ruang miring diantara ruang belajar dan selasar. 
Bila dilihat berdasarkan pengamatan, MIN 3 memiliki bangunan yang masih berupa bangunan kayu dan berusia cukup tua. Halaman sekolah yang berupa bata pres dan cor semen terkadang masih banyak permukaan yang tidak rata, kemudian untuk menuju kelas ataupun selasar yang permukaannya yang lebih tinggi dari halaman tidak memiliki bidang miring untuk kemudahan perpindahan peserta didik yang menggunakan alat bantu gerak. Maksud adanya bidang miring tersebut merupakan sebuah dorongan akan adanya kemandirian pribadi, tidak mengharap bantuan orang lain untuk menggunakan akses fasilitas tersebut.

Apabila kita telaah bangunan lama memang tidak sesuai dengan standar yang diinginkan, bangunan lama adalah yang masih berupa bangunan semi permanen menggunakan bahan material sebagian besar masih berupa kayu dan tentu saja aturan yang terkait akses belum diberlakukan. Tetapi untuk bangunan yang permanen pun ternyata juga masih belum sesuai dengan ${ }^{12}$ yang mengamanahkan adanya hak penyandang disabilitas untuk mendapatkan aksesibilitas untuk memanfaatkan fasilitas publik.

Terkait pengetahuan pendidikan bagi kaum disabilitas, saat pelaksanaan observasi di MIN 3 Kota Banjarmasin tim peneliti mengadakan wawancara dengan Kepala Madrasah Ibtidaiyah Negeri (MIN) 3 yaitu Dra $\mathrm{Hj}$. Juhairiah dalam keterangan beliau menyebutkan bahwa untuk masalah Perda No. 17 Tahun 2013 tentang Perlindungan dan Pemenuhan Hak Penyandang Disabilitas beliau menyatakan belum mengetahu secara langsung karena sosialisasi yang belum ada. Tetapi beliau mengetahui hal tersebut melalui Kementrian Agama melalui Seksi Pendidikan Madrasah. Beliau menyebutkan pula bahwa ada instruksi terkait pemenuhan hak difabel di Madrasah Ibtidaiyah untuk memberikan kesempatan sebesar-besarnya dalam pemenuhan hak tersebut. ${ }^{13}$

Tetapi yang harus menjadi perhatian adalah bahwa pedoman teknis terkait pendidikan bagi kaum difabel masih belum ada. Hal ini tentu menjadi hambatan dalam pelaksanaan hal tersebut. Sekolah pada dasarnya setelah menerima instruksi dari Kementrian Agama untuk menerima peserta didik difabel melalui penerimaan siswa baru dengan kuota lingkungan sekitar yang dapat masuk tanpa tes, tentu dengan persyaratan

12 Kementrian Hukum dan HAM, Undang-Undang Nomor 8 Tabun 2016 Tentang Penyandang Disabilitas, 2016.

${ }^{13}$ Wawancara dengan Dra Hj. Juhairiah pada, 18 Oktober 2018 di MIN 3 Banjarmasin 
tertentu. Fasilitas untuk menunjang akses bagi gerak difabel memang diakui oleh pihak madrasah dalam hal ini Kepala MIN 3 Banjarmasin. Terkait hal ini beliau pun memberikan saran bagi pemerintah apabila memang ingin hal ini dilaksanakan, maka agar mempersiapkan anggaran untuk penyediaan sarana dan prasarana terkait hal tersebut. Kemudian terkait dengan guru dalam melaksanakan proses pembelajaran diharapkan agar diberi pelatihan ataupun penataran, atau studi banding ke sekolah yang telah menerapkan hal tersebut. Hal ini dikarenakan para guru belum pernah mengajari peserta didik yang memiliki kebutuhan khusus.

Kesiapan sekolah ini tentu harus ditunjang oleh kurikulum yang benar-benar mengakomodir pemenuhan kebutuhan pendidikan bagi kaum difabel. Kurikulum pada MIN 3 masih merupakan kurikulum bagi peserta didik umum, atau tanpa kendala pada fisik. Hal terkait ini pun telah ditanyakan kepada salah satu guru MIN 3 yaitu Hermawati yang dalam keterangannya malah tidak mengetahui secara persis tentang Perda ini. Beliau menyatakan pernah mendengar kabar mengenai perda tersebut namun tidak mengetahui secara pasti Perda tersebut mengatur tentang apa, beliau hanya mengetahui ada hak kaum difabel yang harus dipenuhi. Pada kesempatan yang sama beliau juga menyatakan ketidak tahuannya tentang hal yang diatur terkait pendidikan bagi kaum difabel seperti kurikulum ataupun bagaimana pengaturan proses duduk peserta didik dengan kebutuhan khusus. ${ }^{14}$

Berdasarkan ketersediaan fasilitas akses (kemudahan) untuk siswa disabilitas maka MIN 3 dapat dikatakan belum memiliki kemudahan akses. Hal ini dapat dilihat melalui bangunan yang masih banyak perbedaan tinggi lantai antara kelas dan selasar yang masih tidak rata, kemudian tidak adanya jalur pemandu bagi siswa difabel. Apabila dilihat berdasarkan observasi penelitian maka sarana dan prasarana tidak memunculkan asas kemandirian (tidak memerlukan bantuan orang lain), karena fasilitas penunjang masih tidak bisa dipenuhi. Hal tersebut juga dikarenakan kondisi bangunan yang sudah berumur tua.

MIN 3 merupakan sekolah dengan bangunan bertingkat dan untuk lantai dasar saja masih belum ramah untuk difabel, apalagi akses untuk ke lantai atas. Bentuk tangga pun masih dapat dikatakan kembali adalah belum ramah terhadap akses kaum difabel.

14 Wawancara dengan Hermawati (Guru MIN 3 Banjarmasin) pada tanggal 18 Oktober 2018 di MIN 3 Banjarmasin 


\section{MIN 4 Kota Banjarmasin}

Ruang kelas yang terdapat di MIN 4 Kota Banjarmasin dapat dikatakan dalam hal lantai yang sudah rata dan tidak ada hambatan bagi kursi roda. Hal ini dikarenakan lantai sudah menggunakan bahan material keramik atau porselin. Namun meja masih merupakan meja yang tidak ramah terhadap kaum difabel khususnya pengguna kursi roda. Bentuk meja merupakan meja kayu dengan dimensi yang tidak dapat atau bahakan menyulitkan pengguna kursi roda. Hambatan tersebut dapat dilihat melalui bagian kayu yang menjadi tempat meletakkan kaki siswa yang berfungsi juga sebagai penguat meja belajar. Tetapi pada sisi lain penguat dan peletak kaki siswa tersebut malah menyulitkan akses kursi roda menggunakan meja tersebut.

Arena bermain siswa di halaman sekolah yang sering dipergunakan untuk upacara kenaikan bendera menggunakan material bata pres yang memang tidak akan bisa rata permukaanya, apalagi di tanah rawa yang memang cenderung tidak stabil. Hal ini tentu berakibat akan ada kesulitan akses bagi peserta didik (kalau ada) yang berkursi roda. Kemudian hal tersebut semakin menjadi tidak ramah dikarenakan kembali bidang miring seperti ram yang tidak tersedia untuk menghubungkan halaman dengan selasar dan ruang belajar yang tidak tersedia. Memang tinggi permukaan antara halaman dengan selasar setebal sebuah papan, namun hal tersebut masih memerlukan tenaga ekstra bagi pengguna kursi roda untuk melewatinya dan selasar dengan ruang kelas memang harus ada bidang miring sebagai penghubungnya.

Wawancara dengan Kepala Madrasah Drs. Abdul Karim Jailani 4 Kota Banjarmasin menjadi salah satu yang harus dicermati terkait pelaksanaan pendidikan setara ini. Beliau menyebutkan bahwa MIN 4 memang tidak memiliki peserta didik berkebutuhan khusus. Beliau juga seperti Kepala Madrasah lainnya mengungkapkan bahwa beliau pribadi maupun instansi yang beliau pimpin belum pernah diundang dalam sosialisasi terkait Perda yang dimaksud. Hal ini tentu berakibat pada ketidak tahuan instansi bahwa ada Perda yang mengatur hal tersebut, yang salah satu bidangnya adalah pendidikan. ${ }^{15}$

Sosialisasi tentu menjadi penting bagi pihak madrasah karena akan mengukur kemampuan madrasah dalam menerapkan peraturan tersebut.

15 Wawancara dengan Drs. Abdul Karim Jailani pada tanggal 22 Oktober 2018 di MIN 4 Kota Banjarmasin 
Karena Perda juga tentu bersumber pada produk hukum diatasnya. Sosialisasi tersbut dikatakan memang tidak pernah diterima pihak Madrasah.

Senada dengan Kepala Madrasah, berdasarkan wawancara dengan salah satu guru MIN 4 Kota Banjarmasin yaitu Suriansyah, menyatakan bahwa guru tidak pernah ada pelatihan terkait pendidikan disabilitas dan sosialisasi terkait pun tidak ada. Hal ini juga mengaskan dari wawancara tersebut, bahwa MIN 4 tidak pernah menerima siswa berkebutuhan khusus sehingga MIN 4 dalam hal pelatihan guru terkait disabilitas baik dengan instansi lain ataupun mandiri tidak pernah melaksanakan hal tersebut. ${ }^{16}$

5. MIN 5 Kota Banjarmasin

MIN 5 memiliki bangunan yang cukup baik walau ada beberapa bangunan yang memerlukan perhatian khusus. Keberadaan bangunan yang merupakan bangunan lama tentu pada tahap selanjutnya ada kemungkinan renovasi dan dapat memperhatikan pembangunan berdasarkan peraturan terkait akses tersebut. Hal ini tentu menjadi sebuah modal yang baik kedepannya untuk menciptakan fasiltas yang memudahkan seluruh peserta didik. Namun akses menuju MIN 5 Kota Banjarmasin memang tidak terlalu bagus karena jalan menuju MIN yang tidak terlalu besar, tetapi bisa dikata Akses menuju lantai dua pada MIN 5 Kota Banjarmasin dapat dikatakan belum ramah karena untuk anak berkebutuhan khusus, tangga seperti gambar diatas masih belum bisa diakses oleh peserta didik tersebut. Memang bicara ideal tentu menggunakan atau tangga dilengkapi dengan lif tangga (stairway lift) atau jalur ram/bidang jalur atau jalan yang landau pengganti anak tangga untuk menuju lantai atas.

Kondisi ruangan belajar cukup baik, namun untuk beberapa hal yang dikaitkan dengan akses terhadap peserta didik berkebutuhan khusus maka meja siswa dapat dikatakan belum ramah kemudian ruangan yang memang terkesan agak sempit dan terlalu penuh sehingga agak merepotkan gerak bagi siswa berkebutuhan khusus.

Sempit dan luasnya ruangan memang tidaklah menjadi sebuah indikator ramah atau tidaknya sebuah sekolah bagi siswa atau peserta didik berkebutuhan khusus, tetapi sebuah ruangan yang ideal yang terlihat luas

16 Wawancara dengan Suriansyah (guru MIN 4 Kota Banjarmasin, pada tanggal 22 Oktober 2018 di MIN 4 Kota Banjarmasin. 
tentu menjadi sebuah tuntutan masyarakat yang peduli terhadap pendidikan yang setara.

Akses menuju kamar kecil boleh dikatakan kurang bahkan tidak ramah dan saat masuk ke kamar kecil tersebut akan Nampak sebuah kamar kecil yang memang peruntukannya untuk orang yang tidak memiliki masalah terhadap gerak dirinya. Kondisi kamar kecil tersebut juga harus kita katakan tidak layak dan tidak mudah digunakan peserta didik yang memiliki keterbatasan. Pada bagian pintu, seperti terlihat di gambar memang tidak standar menggunakan pintu yang bisa dibuka dari luar untuk kondisi darurat. Kemudian kondisi kamar mandi yang cukup sempit dan tidak dilengkapi fasilitas pendukung atau penunjang bagi kaum difabel juga harus menjadi perhatian bersama. Tinggi lantai juga berbeda antara bagian dalam dan bagian luar kamar kecil juga harus menjadi perhatian bersama.

Terkait dengan banyaknya fasilitas yang belum ramah difabel, maka hasil wawancara dengan Kepala Madrasah yaitu H. Abdul Kadir, S.Pd.I. bahwa pihak MIN 5 Kota Banjarmasin tidak memperoleh pengetahuan yang cukup atau belum ada sosialisasi dengan pihak yang berwenang terkait masalah tersebut. Dengan kata lain pihak MIN 5 belum ada mendapat sosialisasi dari Pemprov Kalimantan Selatan terkait akses pendidikan bagi kaum disabilitas pada khususnya. Dalam pelaksanaan proses pembelajaran sampai saat penelitian dilakukan di MIN 5, disebutkan oleh Kepala Madrasah bahwa MIN 5 Kota Banjarmasin tidak memiliki peserta didik yang dimaksud atau berkebutuhan khusus. ${ }^{17}$

Ketika ditanyakan lebih lanjut maka ketidaktahuan ini mengakibatkan MIN 5 juga tidak memberikan kuota bagi peserta didik berkebutuhan khusus. Hal tersebut juga membuat orang tua murid sepertinya lebih mempercayai anaknya untuk bersekolah di SLB yang ada. Fasilitas terkait hal tersebut pun diakui oleh Kepala Madrasah memang belum ramah terhadap peserta didik berkebutuhan khusus. Karena hal tersebut juga membuat MIN 5 tidak memiliki guru khusus untuk mendukung hal tersebut.

Pendapat dari salah satu guru MIN $5 \mathrm{H}$. Khairuddin juga menyebutkan bahwa selama ini memang tidak ada sosialisasi, apalagi pelatihan terkait hal tersebut. Temuan ini semakin menegaskan bahwa memang tidak ada kesiapan yang cukup, baik dari pembuat kebijakan

17 Wawancara dengan H. Abdul Kadir, S.Pd.I pada tanggal, 24 Oktober 2018 di MIN 5 Kota Banjarmasin 
maupun pelaksana kebijakan terkait penyelenggaraan pendidikan setara dan tanpa terkecuali khususnya bagi peserta didik berkebutuhan khusus. ${ }^{18}$

\section{Temua dan Tinjauan}

Aksesibilitas sebuah infrastruktur pada sebuah bangunan merupakan hal yang paling penting untuk menunjang keamanan dan kenyamanan semua orang yang ada di dalamnya. Tidak terkecuali bagi penyandang disabilitas, khususnya tunadaksa. ${ }^{19}$ Berbicara mengenai dasar hukum dengan penerapan yang ada tentu menjadi sebuah diskusi yang akan sangat panjang lebar dan penuh dengan deskripsi yang penuh dengan sebuah realita yang kadang tidak terlalu sesuai dengan keinginan produk hukum yang telah ada. Asas kesetaraan tentu menjadi sebuah semangat dalam terbitnya beberapa produk hukum.

Ragam penyandang disabilitas meliputi 1) Penyandang Disabilitas Fisik, 2) Penyandang Disabilitas Intelektual, 3) Penyandang Disabilitas Mental, 4) Penyandang Diabilitas Sensorik. Hal ini tertulis pada pasal 4 UU No.4 Tahun 1997. ${ }^{20}$ Paling tidak terdapat tiga aspek yang paling berpengaruh terhadap aspirasi anak difabel. Ketiganya meliputi: a) tujuan atau target b) kesadaran akan kondisi perbedaan diri dan analisis faktor risiko atas kegagalan, dan c) respon sosial. Tiga faktor tersebut sangat menentukan aspirasi bersekolah seperti apa yang nantinya terbentuk dalam benak anak difabel. ${ }^{21}$

Penelitian ini mencoba melihat akses kesetaraan kaum disabiltas sebagai sesama warga Negara yang memperoleh kesempatan yang sama untuk memenuhi hak dasarnya dan sebagai peserta didik yang tidak kesulitan untuk mengakses fasilitas pendidikan yang terdapat didalamnya. Dengan kata lain kami mencoba lebih menekankan pada ragam disabilitas yang telah ditentukan, yaitu disabilitas fisik saja. Hal ini berkaitan dengan kecenderungan kesiapan pada bangunan pada fasilitas umum yang dewasa ini mulai memperhatikan akses kemudahan bagi penyandang disabilitas terebut.

Secara garis manusia Indonesia berhak melakukan pengembangan diri melalui kebutuhan dasar yang dipenuhi kemudian berhak mendapat pendidikan

18 Wawancara dengan H. Khairuddin, pada tanggal 24 Oktober 2018 di MIN 5 Kota Banjarmasin

19 Ezza Oktavia Utami, Santoso Tri Raharjo, and Nurliana Cipta Apsari, "Aksesibilitas Penyandang Tunadaksa," Jurnal Penelitian \& PPM Vol 5, No., no. Vol 5, No. 1 April 2018 (2018): 83-101.

${ }^{20}$ Sekertaris Negara RI, Undang-Undang No. 4 Tabun 1997 Tentang Penyandang Cacat.

${ }^{21}$ Miftakhuddin, "Kecenderungan Putus Sekolah Difabel Usia Pendidikan Dasar Di Jember," Inklusi: Journal of Disability Studies V, no. Vol. V, No. 1 Januari-Juni (2018). 
dan memperoleh manfaat atasnya dan meningkatkan kualitas hidupnya seperti tertulis dalam pasal 28C. Dalam UUD menyebutkan bahwa setiap warga Negara berhak mendapat pendidikan, dengan kata lain tanpa kecuali atau seluruh warga Negara berhak mendapatkan hal tersebut atau pendidikan. ${ }^{22}$

Hal ini dapat kita maknai bahwa Negara memang harus hadir untuk memenuhi hal ini tanpa kecuali. Keterbatasan fisik tentu tidak menjadi kendala bagi setiap warga Negara untuk memenuhi salah satu kebutuhan dasarnya karena Negara yang menyediakan akses itu dan tidak mempermasalahkannya. Kendala mungkin akan didapat oleh penyelenggara pendidikan pada setiap jenis, jalur dan jenjang pendidikan, karena pihak penyelenggaralah yang akan menjalankan kebijakan tersebut. Sosialisasi akan produk hukum ini tentu dirasa sangat penting agar penyelenggara dan pengguna pendidikan akan memperoleh kepastian hukum terkait ini.

Akses tentu menjadi hal utama dan pada tahap akhirnya fasilitas penunjang hal ini tentu menjadi sebuah keharusan dalam pelaksanaan aksesibilitas pendidikan bagi kaum disabilitas di sekolah umum, yang melandaskan penyelenggaraan pendidikan inklusif. Fasilitas penunjang kebijakan tersebut memang dapat dikatakan belum siap untuk dilaksanakan, hal tersebut didasari banyaknya fasilitas yang sulit diakses bagi peserta didik yang menggunakan alat tambahan untuk perpindahan tubuh mereka, misalnya dalam toilet, dan tangga serta akses menuju selasar yang masih berupa tangga yang tentunya menghambat gerak peserta didik berkebutuhan khusus.

Aksesibilitas tentu menjadi sangat penting dalam hal ini, hal tersebut menjadi sebuah upaya penyelenggara pendidikan untuk menciptakan akses pendidikan seluas-luasnya bagi seluruh warga negara.

Penyandang disabilitas memiliki hak-hak yang tercantum dan berbagai hak dasar ada didalamnya, salah satunya yaitu aksesibilitas yang didefinisikan sebagai sebuah kemudahan yang disediakan untuk penyandang disabilitas guna mewujudkan kesamaan kesempatan. ${ }^{23}$

Kesamaan kesempatan secara tersirat telah dinyatakan bahwa ada instruksi untuk menerima peserta didik yang memiliki keterbatasan, namun niat baik ini memang belum terasa optimal karena dari wawancara yang telah dilaksanakan dengan para narsumber, yaitu guru beserta unsur pimpinan atau

\footnotetext{
${ }^{22}$ Negara, Undang-Undang Dasar 1945.

${ }^{23}$ Kementrian Hukum dan HAM, Undang-Undang Nomor 8 Tahun 2016 Tentang Penyandang Disabilitas.
} 
Kepala Madrasah menyatakan bahwa rata-rata Madrasah masih belum terdapat siswa berkebutuhan khusus atau difabel atau peserta didik disabilitas.

Hal tersebut mungkin dikarenakan kurangnya pengetahuan dan sosialisasi terkait hal tersebut. Peran masyarakat tentu juga diharapkan dalam hal ini. Kita menginginkan masyarakat yang mampu menciptakan lingkungan sekitar sekolah menjadi lingkungan yang ramah bagi peserta didik difabel, atau menjadi rekan bagi sekolah dalam hal ini MIN untuk mempersiapkan fasilitas minimal terkait dengan akses tersebut.

Pembuatan fasilitas penunjang untuk mewujudkan MIN yang ramah bagi peserta didik berkebutuhan khusus tentu menjadi hal yang diharapkan bersama, walau untuk menjalankannya memerlukan persiapan yang sangat detail dan menyeluruh. Persiapan tersebut juga menyangkut dengan kemampuan biaya yang tidak sedikit, kemudian diperlukan pula adanya guru pendamping siswa disabilitas. Hal seperti ini tentu perlu dipersiapkan dengan matang, sehingga program ini dilakukan dengan optimal dan tidak terburuburu.

Masalah persyaratan teknis fasilitas dan aksesibilitas pada bangunan gedung dan lingkungan telah ada 12 tahun yang lalu seperti tertuang pada Permen PU No. 30 Tahun 2006 tentang pedoman teknis fasilitas dan aksesibilitas pada bangunan gedung dan lingkungan menyebutkan beberapa hal yang harus sesuai dengan pedoman teknis sesuai hal tersebut antara lain, jalur pemandu, area parker, pintu, ram (jalur miring), tangga, lif, lif tangga (staimway lift), toilet, pancuran, westafel dan hal lain. ${ }^{24}$ Penyediaan fasilitas tentu menjadi hal yang harus dipersiapkan. Kerjasama antar instansi tentu akan sangat baik karena Perda akan mengatur teknis terkait hal tersebut. Perda tersebut dikeluarkan pemerintah provinsi Kalimantan Selatan melalui Perda No. 17 Tahun 2013 tentang perlindungan dan pemenuhan hak penyandang disabilitas, yang salah satu fokus perhatiannya juga pada bidang pendidikan.

Akses menjadi hal yang sangat penting dalam hal ini, dan hal penting lainnya adalah sambutan hangat dari masyarakat atau lingkungan sekolah yang terdiri atas tenaga pendidik, tenaga kependidikan dan peserta didik lainnya. Sehingga tercipta suasana pendidikan inklusi yang dapat pula berupa penerimaan siswa non difabel yang dapat mengerti dan tentu memaklumi kondisi peserta didik berkebutuhan khusus, terutama terkait dengan gerak.

\footnotetext{
${ }^{24}$ Kementrian Pekerjaan Umum, Peraturan Menteri Pekerjaan Umum No. 30 Tentang Pedoman Teknis Fasilitas Dan Aksesibilitas Pada Bangunan Gedung Dan Lingkungan, 2006.
} 
Hambatan - hambatan sosial-budaya (cultural and sosial barriers) dan ekonomi seperti diungkapkan di atas adalah bagian dari kenyataan yang dialami difabel di Indonesia. Mengenai hal ini tentu sosialisasi dan edukasi yang secara terus menerus terhadap masyarakat umum tentu menjadi sangat penting agar peristiwa yang membatasi interaksi dan integrasi kaum disabilitas pada masyarakat umum tidak dihalangi dan dibatasi oleh ketidak tahuan masyarakat megenai hal tersebut.

Hak pendidikan untuk penyandang disabilitas meliputi hak; a) mendapatkan pendidikan yang bermutu pada satuan pendidikan di semua jenis, jalur dan jenjang pendidikan secara inklusif dan khusus. b) mempunyai kesamaan kesempatan untuk menjadi pendidik atau tenaga kependidikan pada satuan pendidikan di semua jenis, jalur dan jenjang pendidikan, c) mempunyai kesamaan kesempatan sebagai sebagai penyelenggara pendidikan yang bermutu pada satuan pendidikan di semua jenis, jalur dan jenjang pendidikan dan d) mendapatkan akomodasi yang layak sebagai peserta didik. ${ }^{25}$

Ketika tim melakukan observasi pada beberapa MIN yang ada di Banjarmasin, memang tidak dapat dipungkiri bahwa fasilitas pendidikan yang berada di bawah lingkungan Kementrian Agama dapat kami katakana belum ramah bagi kaum disabilitas. Pernyataan ini didasarkan oleh fasilitas yang sangat belum memadai bagi kaum disabilitas. Beberapa faktor yang menegaskan pernyataan ini antara lain, bahwa MIN selaku pelaksana atau operator pendidikan dasar di lingkungan Kementrian Agama tidak memiliki jalur bagi kaum disabilitas pada akses naik turun lantai (tangga) yang hanya berfungsi bagi peserta didik yang tidak memiliki kesulitan dalam mengakses fasilitas tersebut.

Terkait akses bagi penyandang disabilitas disebutkan pada bagian keempat belas pada bagian hak aksesibilitas meliputi a) mendapatkan aksesibiltas untuk memanfaatkan fasilitas publik dan b) mendapatkan akomodasi yang layak sebagai bentuk aksesibiltas bagi individu. ${ }^{26}$ Hal ini menjadi sebuah amanat bagi setiap pengelola fasilitas publik salah satunya adalah sekolah sebagai suatu lembaga yang tidak boleh mengabaikan hak-hak individu. Karena pada butir b kembali mengaskan bahwa penyandang disabilitas diharapkan akan mendapat kelayakan dalam akses terhadap fasilitas tersebut.

\footnotetext{
${ }^{25}$ Kementrian Hukum dan HAM, Undang-Undang Nomor 8 Tabun 2016 Tentang Penyandang Disabilitas.

${ }^{26}$ Ibid.
} 
Fasilitas penting yang terdapat di MIN pun tentu harus kita nilai ramah atau tidaknya. Selama observasi berlangsung penulis dapat katakan toilet yang terdapat pada 5 (lima) MIN dapat dikatakan tidak ramah dan tidak layak. Hal tersebut didasarkan temuan di lapangan yang dilakukan oleh penulis yang menyimpulkan bahwa fasilitas tersebut susah di akses dan memang tidak sesuai dengan spesifikasi berdasarkan Permen PU. Selasar kelas pun untuk menuju fasilitas tersebut masih menggunakan anak tangga dan tidak memiliki jalur akses yang miring untuk mudah dijalani oleh pengguna kursi roda misalnya.

Pemerintah dan Pemerintah Daerah memiliki kewajiban untuk menyelenggarakan dan memberi kemudahan serta memfasilitasi pendidikan untuk Penyandang Disabilitas di setiap jalur, jenis, dan jenjang pendidikan. ${ }^{27}$ Hal ini merupaka suatu penegasan bahwa pemerintah baik pusat maupun daerah harus hadir untuk pelaksanaannya dan tentu sesuai dengan kewenangannya.

Pasal tersebut dengan salah satu butirnya juga menegaskan bahwa pemerintah ataupu pemerintah daerah wajib mengikutsertakan anak penyandang disabilitas dalam program wajib belajar 12 tahun. Ada hal yang menarik selanjutnya dalam dasar hukum ini adalah bahwa pemerintah daerah wajib mengutamakan anak penyandang disabilitas bersekolah di dekat tempat tinggalnya. Hal ini tentu akan sangat berkaitan dengan data yang harus valid. Terkait hal tersebut sepertinya sudah mulai dirintis system data untuk dapat data terkait hal tersebut.

Penerbitan kartu penyandang disabilitas (KPD) yang bertujuan untuk memperoleh akses layanan dalam penghormatan, pemajuan, perlindungan dan pemenuhan hak penyandang disabilitas.Penerbitan KPD tentu akan membantu terkait data yang diperlukan. Data tersebut dapat digunakan sebagai dasar terkait penyandang disabilitas disekitar sekolah. Namun hal tersebut perlu di sosialisasikan kembali karena KPD merupakan program yang masih sangat baru. Tetapi hal ini tentu menjadi angin baik terkait pendataan terkait penyandang disabilitas.

Terkait akses pendidikan bagi penyandang disabilitas tentu diperlukan sinergitas yang baik antara keluarga, sekolah dan masyarakat tentunya. Karena apabila pihak sekolah memberikan akses yang luas bagi penyandang disabilitas, namun pada sisi lain keluarga tidak mencari tahu terkait hal tersebut maka akses tersebut menjadi sia-sia dan tidak bermakna. Keluarga tentu juga sangat berpengaruh untuk mengetahui hal yang berkaitan dengan hal tersebut.

${ }^{27}$ Ibid. 
Sosialisasi terkait kebijakan tentu menjadi sangat penting, karena MIN selaku operator atau pelaksana kebijakan tentu tidak bisa selalu mengundang saja tapi perlu bantuan pihak keluarga untuk menyukseskan program tersebut. Dengan kata lain perlunya peran keluarga untuk menyekolahkan anaknya, dengan konsekuensi yang harus ditanggung tentunya. Akses bagi penyandang disabilitas dimaksudkan agar tidak ada penggolongan atai diferensiasi sosial terkait penyandang disabilitas khususnya dalam bidang pendidikan yang memang pada prinsipnya dapat menjadi salah satu saluran mobilitas vertikal.

MIN selaku salah satu penyelenggara pendidikan dasar di bawah Kementrian Agama belum dapat dikatakan banyak mengetahui hal terkait penerapan aturan atau dasar hukum terkait akses pendidikan setara tersebut. Pemerintah Daerah wajib memfasilitasi pembentukan Unit Layanan Disabilitas (ULD) untuk mendukung penyelenggaraan pendidikan inklusif salah satunya pada tingkat dasar. ULD menurut UU tersebut mempunyai fungsi untuk meningkatkan kompetensi pendidik maupun tendik di sekolah regular dalam menangani peserta didik penyandang disabilitas. Hal ini apabila kita hubungkan dengan kenyataan di berbagai MIN tersebut maka amanat UU ini memang masih belum dijalankan.

Merencanakan dan melaksanakan pembangunan bangunan gedung dan lingkungan, harus dilengkapi dengan penyediaan fasilitas dan aksesibilitas. Memang untuk menjadikan sebuah bangunan menjadi ramah disabilitas akan memerlukan ukuran dasar ruang, jalur pedestrian, jalur pemandu, ram, tangga dan lif tangga serta toilet yang ramah disabilitas.

Peraturan tersebut telah membagi peraturan tersebut menjadi dua penerapan yaitu penerapan wajib dan tidak wajib. Penerapan wajib terdiri atas bangunan gedung yang telah ada, bangunan gedung yang akan dibangun, bangunan gedung yang mengalami perubahan dan penambahan, bangunan gedung yang dilindungi, bangunan gedung yang merupakan bagunan darurat. Penerapan tidak wajib terdiri atas Bangunan yang dapat dibuktikan (fasilitas aksesibilitas tidak dapat dipenuhi berdasarkan pendapat ahli, bangunan sementara, bangunan penunjang struktur dan bangunan untuk peralatan, bagian bangunan yang hanya dipakai dengan cara tertentu.

Mengapa kesetaraan menjadi penting, utamanya dalam bidang pendidikan khususnya di Banjarmasin. Pada Perda terkait disebutkan bahwa setiap penyelenggara pendidikan pada semua jalur, jenis dan jenjang pendidikan memberikan kesempatan dan perlakuan yang setara dan berkewajiban 
menerima peserta didik Penyandang Disabilitas. ${ }^{28}$ Pada butir selanjutnya disebutkan akan adanya kewajiban memberikan pelayanan yang tentu menekankan kualitas yang memang harus disesuaikan dengan kondisi dan potensi peserta didik penyandang disabilitas.

Apabila kita telaah maka hal ini menjadi sebuah penegasan bahwa sekolah regular memang seharusnya juga menerima peserta didik tanpa persyaratan (menerima peserta didik berkebutuhan khusus).

Peningkatan kualitas sarana dan prasarana pendidikan dalam rangka mewujudkan pendidikan yang kondusif, efektif dan bermutu. Sasaran penyelenggara pendidikan yaitu perluasan akses layanan pendidikan secara merata, terjangkau dan bermutu. ${ }^{29}$ Timbul pertanyaan apakah sekolah regular juga menerima peserta didik berkebutuhan khusus, apakah tidak mencampuri domain SLB, maka menjawab hal tersebut kita perlu cermati berdasarkan aturan yang berlaku.

Pendidikan khusus bagi peserta didik dapat pula diselenggarakan pada semua jalur dan jenis pendidikan pada jenjang pendidikan dasar dan menengah. ${ }^{30}$ Dasar ini tentu juga harus mempersiapkan kesiapan baik sarana prasarana maupun tenaga pendidik dan kependidikan. Semoga kedepannya kualitas pendidikan Indonesia semakin meningkat dan tentunya dapat diakses seluruh rakyat Indonesia.

\section{Simpulan}

Berbicara mengenai akses pendidikan bagi siswa berkebutuhan khusus di lingkungan Kementrian Agama dapat kami katakan belum layak dan tidak ramah siswa berkebutuhan khusus. Kemudian kurangnya fasilitas tersebut juga semakin diperparah dengan kurangnya sosialisasi terkait, setiap MIN yang kami teliti ternyata dari para pendidik banyak yang belum mengetahui tentang Perda yang dimaksud. Hal ini dikarenakan kurangnya sosialisasi yang dilakukan Pemerintah Daerah.

Hal yang perlu dibenahi terkait pendidikan setara di Kota Banjarmasin khususnya, adalah jangan sampai ada kesan eksklusifitas. Hal tersebut tentu

\footnotetext{
${ }_{28}$ Pemerintah Provinsi Kalimantan Selatan, Peraturan Daerah Nomor 17 Tahun 2013 Tentang Perlindungan Dan Pemenuban Hak Penyandang Disabilitas (Indonesia, 2013), http://banjarmasin.bpk.go.id/wp-content/uploads/2014/09/PERDA-NO-17-TAHUN-2013DISABILITAS.pdf.

${ }^{29}$ Ibid.

30 Kementrian Hukum dan HAM, Peraturan Pemerintah RI Nomor 17 Tabun 2010 Tentang Pengelolaan Dan Penyelenggaraan Pendidikan, 2010.
} 
malah membuat lembaga pendidikan di bawah kementrian agama malah tidak disentuh sosialisasi dari instansi di luar Kemenag.

Pendidikan sebagai salah satu urusan pemerintah merupakan bagian dari pelayanan dasar kepada masyarakat, seperti tertuang dalam UU No. 23 Tahun 2014 tentang Pemerintahan Daerah pada pasal 12. Berdasarkan hak tersebut tentu seharusnya tidak ada lagi perbedaan bahkan diskriminasi lembaga pendidikan dibawah kementrian apapun untuk dapat mengetahui informasi yang berkembang.

\section{Daftar Pustaka}

Kementrian Hukum dan HAM. Peraturan Pemerintah RI Nomor 17 Tabun 2010 Tentang Pengelolaan Dan Penyelenggaraan Pendidikan, 2010.

_. Undang-Undang Nomor 8 Tabun 2016 Tentang Penyandang Disabilitas, 2016.

Kementrian Pekerjaan Umum. Peraturan Menteri Pekerjaan Umum No. 30 Tentang Pedoman Teknis Fasilitas Dan Aksesibilitas Pada Bangunan Gedung Dan Lingkungan, 2006.

Kementrian Pendidikan Nasional. Peraturan Mentri Pendidikan Nasional Nomor 70 Tahun 2009 Tentang Pendidikan Inklusif Bagi Peserta Didik Yang Memiliki Kelainan Dan Memiliki Potensi Kecerdasan Dan/Atau Bakat Istimewa. Indonesia, 2009. http://kelembagaan.ristekdikti.go.id/wpcontent/uploads/2016/11/Permen-No.-70-2009-tentang-pendidiianinklusif-memiliki-kelainan-kecerdasan.pdf.

- Undang-Undang No 20 Tahun 2003 Tentang Sistem Pendidikan Nasional, 2003. https://kemenag.go.id/file/dokumen/UU2003.pdf.

Mahabbati, Aini. "Kebijakan, Implementasi Dan Isu Strategis Pendidikan Bagi Individu Berkebutuhan Khusus." Jurnal Pendidikan Islam 3, no. 1 (2014): 31. http://jurnaljpi.com/index.php/JPI/article/view/38.

Miftakhuddin. "Kecenderungan Putus Sekolah Difabel Usia Pendidikan Dasar Di Jember." Inklusi : Journal of Disability Studies V, no. Vol. V, No. 1 Januari-Juni (2018).

Muhadjir. Metodologi Penelitian Kualitatif Edisi IV. Yogyakarta: Rake Sarasin, 2002.

Negara, Sekretariat. Undang-Undang Dasar 1945, 2002. http://jdih.pom.go.id/uud1945.pdf.

Pemerintah Provinsi Kalimantan Selatan. Peraturan Daerah Nomor 17 Tabun 2013 Tentang Perlindungan Dan Pemenuban Hak Penyandang Disabilitas. 
Indonesia, 2013. http:/ /banjarmasin.bpk.go.id/wpcontent/uploads/2014/09/PERDA-NO-17-TAHUN-2013DISABILITAS.pdf.

Rahmad. "Pendidikan Setara Bagi Disabilitas." Banjarmasin Post. Banjarmasin, 2017.

Sekretaris Negara RI. Undang-Undang No. 4 Tabun 1997 Tentang Penyandang Cacat, 1997. http://www.kpai.go.id/files/uu/UU-NOMOR-4-TAHUN1997-TENTANG-PENYANDANG-CACAT.pdf.

Soehartono, Irawan. Metode Penelitian Sosial. Bandung: PT. Remaja Rosdakarya, 2002.

Utami, Ezza Oktavia, Santoso Tri Raharjo, and Nurliana Cipta Apsari.

"Aksesibilitas Penyandang Tunadaksa." Jumal Penelitian \& PPM Vol 5, No., no. Vol 5, No. 1 April 2018 (2018): 83-101.

Yusraini. "Kebijakan Pemerintah Terhadap Pendidikan Inklusif." Media Akademika Vol. 28 No (2013).

\section{Daftar Wawancara}

Wawancara dengan Abdul Kadir, S.Pd.I hari Rabu, 10 Oktober 2018 diruang Kepala Sekolah MIN 1 Banjarmasin

Wawancara dengan Drs. Kamal Naser pada tanggal 15 Oktober 2018 di MIN 2 Banjarmasin

Wawancara dengan Dra Hj. Juhairiah pada tanggal 18 Oktober 2018 di MIN 3 Banjarmasin

Wawancara dengan Hermawati (Guru MIN 3 Banjarmasin) pada tanggal 18 Oktober 2018 di MIN 3 Banjarmasin

Wawancara dengan Drs. Abdul Karim Jailani pada tanggal 22 Oktober 2018 di MIN 4 Kota Banjarmasin

Wawancara dengan Suriansyah (guru MIN 4 Kota Banjarmasin, pada tanggal 22 Oktober 2018 di MIN 4 Kota Banjarmasin.

Wawancara dengan H. Abdul Kadir, S.Pd.I pada tanggal, 24 Oktober 2018 di MIN 5 Kota Banjarmasin

Wawancara dengan H. Khairuddin, pada tanggal 24 Oktober 2018 di MIN 5 Kota Banjarmasin 
